\title{
КОМП'ЮТЕРНІ ТЕХНОЛОГІЇ ЯК СИСТЕМОТВІРНИЙ ЧИННИК ПЕРЕХОДУ ДО ІНКЛЮЗИВНОГО НАВЧАННЯ ОСІБ ІЗ ПОРУШЕННЯМИ ЗОРУ
}

Тулашвілі Ю. Й. Комп'ютерні технологї̈ як системотвірний чинник переходу до інклюзивного навчання осіб із порушеннями зору.

У статті розглянуто роль у навчанні людей із порушеннями зору сучасних інформаційних комп 'ютерних технологій, а також застосування їх у процесі професійної підготовки студентів обмеженими можливостями в умовах інклюзивного навчання.

Ключові слова: студент з обмеженими можливостями, професійна підготовка, сліпий, інформаційні технології, інклюзивне навчання.

Тулашвили Ю. И. Компьютерные технологии как ситемообразующий фактор перехода к инклюзивному обучению личностей с нарушением зрения.

В статье рассмотрены роль современных информационных компьютерных технологий в обучении людей со слепотой, а также применение их в процессе профессиональной подготовки студентов с ограниченными возможностями в условиях инклюзивного обучения.

Ключевые слова: студент с ограниченными возможностями, профессиональная подготовка, слепой, информационные технологии, инклюзивное обучение.

Tulashvili Y. Computer technology as a factor sistemoobrazuyuschy transition to inclusive education of persons with visual impairment.

In the article the role of modern information technologies in computer training for people with blindness, as well as their application in the inclusion education of students with disabilities.

Key words: the disabled student, professional education, blind, information technologies, inclusion in education

Актуальність та постановка проблеми. Гуманістичні процеси надали новий поштовх у розробленні стратегії національного розвитку освіти України за парадигмою широкого залучення людського потенціалу для повнішого його використання в розвитку інформаційного суспільства. Одним із напрямків розв'язання цього завдання $\epsilon$ створення умов для професійної підготовки осіб з порушеннями зору на основі опанування ними комп'ютерними технологіями.

Аспекти залучення осіб з порушеннями зору до активної продуктивної праці в галузі комп'ютерних технологій та інформаційних послуг через їх професійну комп'ютерну підготовку $є$ відносно новими для вітчизняної професійної та вищої педагогіки. Тому особливої актуальності набуває розроблення концептуальних засад впровадження професійної комп'ютерної підготовки в систему реабілітації осіб із порушеннями зору.

Аналіз останніх досліджень та публікацій. Особливості застосування комп'ютерних технологій у процесі професійної підготовки людей, які мають порушення зору, відобразили у своїх працях Д. Димитриченко, Л. Коваленко, І. Порецький, Л. Шауцукова, С. Щедров та інші. Визначено, що сучасний процес навчання інвалідів по зору нерозривно пов’язаний із 
опануванням незрячою та слабозорою людиною основ комп'ютерних технологій. Це, в свою чергу, дозволяє, за активного психологопедагогічного супроводу, використовуючи електронні носії для передавання навчальної інформації, створити умови для інклюзивного навчання осіб 3 порушеннями зору та забезпечити успішність їх фахової підготовки.

Метою статті $\epsilon$ аналіз ролі комп'ютерних технологій у процесі професійної реабілітації інвалідів по зору та розкриття напряму адаптації змісту, методів та форм організації професійної комп'ютерної підготовки в умовах інклюзивного навчання осіб з порушеннями зору.

Виклад основного матеріалу. Поміж сучасних тенденцій у світовій цивілізації, що істотно накладають відбиток на розвиток нашого суспільства, окреслено тенденцію широкої гуманізації освітнього середовища. Модернізація освіти не залишає осторонь і спеціальну професійну освіту людей 3 особливими потребами. Тенденції у сучасних системах професійного навчання інвалідів у контексті парадигми гуманізації освітнього середовища висвітлюють напрям побудови інтегрованої системи фахової освіти осіб із порушеннями зору, яка грунтується на принципах особистісно зорієнтованого навчання.

Із позиції сучасного підходу до організації процесу інтегрованого навчання система професійної підготовки людей з особливими потребами розглядається як комплекс реабілітаційних заходів, результатом яких $\epsilon$ інклюзія інваліда у професійний простір [1, с. 11]. В умовах переходу до інформаційного суспільства людина, незалежно від ïi фізичного стану, особистих потреб та інших обставин, може повністю реалізувати свій потенціал, бути корисною суспільству, відчувати себе повноцінним його членом. Розвиток комп'ютерної техніки та програмного забезпечення посприяв виникненню й подальшому поширенню концепції застосування інформаційних технологій як засобу розвитку компенсаторних пристосувань у людей із порушеннями зору. Адаптивні допоміжні комп'ютерні технології забезпечили доступ зороводепривованим людям до інформації та розкрили їм нові можливості для трудової діяльності.

3 погляду застосування інформаційних технологій як технології адаптації для людей 3 порушеннями зору дефініція поняття «інформаційні технології» набуває нового специфічного змісту. Розкриємо це визначення 3 позиції впливу комп'ютерної техніки на сучасні умови життєдіяльності осіб iз порушеннями зору через адаптивне спрямування інформаційних технологій. Пропонуємо термін «сучасні інформаційні технології адаптації» (CITA) визначати як сукупність методів використання комп'ютернокомунікаційних засобів і програмного забезпечення для збору, організації, зберігання, оброблення, передачі й представлення інформації задля розширення доступності до інформаційних потоків та світових знань людям із фізичними порушеннями, які розкривають їм нові можливості в комунікації, управлінні соціальними, економічними та технічними процесами. 
Модернізація освітнього простору на гуманістичних засадах передбачає переорієнтацію освіти в напрямі особистісно розвивального навчання, тобто спрямованість їі цілей, змісту, методів та форм навчального процесу на конкретного суб'єкта освітньої діяльності, на заохочення й стимулювання його гармонійного розвитку. Форма інтегрованого навчання зороводепривованих осіб у цьому контексті набуває особливого значення. У міжнародній практиці термін «інтегрована освіта» (integration), що раніше широко застосовувався для визначення процесу введення людей 3 особливими потребами в освітнє середовище, всесвітньою організацією 3 питань освіти, науки і культури ЮНЕСКО при ООН був замінений на термін «інклюзивна освіта» (от inclusion - включення), як такий, що більш точно відображає зміст процесу. Наслідком стало введення нового терміну «інклюзивне суспільство», основною ознакою якого є стійкий соціальний розвиток, а рівень соціальної інклюзії стає показником виміру стану демократії в країні [2, с. 7]. Поняття «інклюзивне навчання» визначає процес введення особи із порушеннями зору в навчальне середовище на рівних правах з суб'єктами освіти «в нормі».

Широке використання у навчальному середовищі CITA як системотвірного чинника переходу до інклюзивного навчання осіб 3 порушеннями зору зумовило перехід на такі основні дидактичні методи:

- комунікативний - адаптивні технології створюють альтернативні засоби для читання та писання, що надає можливість отримувати нову інформацію та фіксувати власні думки;

- технічний - використання засобів для створення навчальних матеріалів на електронних носіях;

- технологічний - удосконалюється доступ до джерел інформації. Кожен учень може вільно обирати той чи той програмний засіб залежно від наявності залишкового зору;

- розвивальний - у процесі навчання адаптивні технології забезпечують набуття нових знань для утворення понять про навколишній світ, на базі чого в особи з порушеннями зору розширюються компенсаторні пристосування та формується креативне мислення.

Застосування у навчальному процесі комп'ютерної техніки, яка оснащена засобами CITA, розглядається як основний дидактичний засіб, що значно розширює компенсаторно-розвивальні можливості осіб із порушеннями зору та забезпечує ефективність навчальної підготовки в умовах інклюзивної освіти. Навчально-пізнавальна діяльність суб'єктів освіти із депривацією зору, поряд із впровадженням нових дидактичних методів, нерозривно пов'язана з створенням та функціонуванням служби психолого-педагогічного супроводу, як необхідної умови успішності їх навчання. Система психологопедагогічного супроводу яка грунтується на засобах CITA $\epsilon$ основною умовою для запровадження інклюзивного навчання зороводепривованих суб'єктів освіти. 
Інклюзія незрячих студентів в професійно-технічних та вищих навчальних закладах потребує коригування змісту навчальних дисциплін, модифікацію методів викладання, уточнення критеріїв оцінювання навчальних результатів. Саме на службу супроводу покладається завдання створення позитивного впливу навчання та розвиток суб’єктів освіти 3 порушеннями зору. Система супроводу реалізує такі основні напрями взаємодії суб'єктів навчального процесу:

- адаптивно-організуюча взаємодія між викладацьким складом (суб'єктом викладання) та системою супроводу, результатом якої є: адаптований зміст навчання, що реалізується в індивідуальній траєкторії підготовки, яка враховує психофізіологічний стан зороводепривованої особистості; розроблення спеціальних методів i прийомів навчання, які реалізують особистісно зорієнтований принцип та диференціацію процесу навчання; створення у навчальному закладі спеціалізованої матеріально-технічної бази, функціонування якої спрямовано на компенсування наявних дефектів у зороводепривованих осіб; підготовка спеціалізованого навчально-методичного забезпечення та засобів навчання, які враховують особливості нозології інвалідності; підготовку груп т’юторів для підтримки інвалідів по зору під час аудиторного навчання та на етапі самостійної позааудиторної роботи;

- адаптивно-корегувальна взаємодія між особою з порушеннями зору (суб'єктом навчання) та системою супроводу, результатом якої є: визначення індивідуальних психофізіологічних особливостей суб'єктів навчання 3 порушеннями зору задля врахування в процесі складання індивідуальної траєкторії навчання, для забезпечення ефективності планування обсягів аудиторного та позааудиторного часу навчання; психолого-педагогічна адаптація змісту навчання в процесі підготовки до тиражування аудіозаписів лекційних матеріалів, електронних засобів із навчальним матеріалом; виготовлення «наочних» засобів, тифлоілюстрацій для тактильного сприймання незрячими особами; навчання зороводепривованих суб'єктів освіти користуватись адаптивними засобами: комп'ютером, спеціальним програмним забезпеченням, екранними лупами, Брайлівськім монітором, Брайлівськім принтером та іншими засобами;

- адаптивно-формувальна взаємодія між суб’єктом викладання та суб’єктом навчання, що полягає в реалізації принципу активної співпраці між усіма суб'єктами навчально-виховного процесу через: активний контроль під час заняття доступності навчальної інформації та застосування дидактичних методів шляхом підтримання необхідного контакту з тим, хто навчається, задля здійснення моніторингу за його навчальними діями; реалізацію завдання викладацького складу в наданні систематичних, регулярних консультацій суб'єктам освіти із дефектом зору задля виявлення правильності уяви про об'єкт, процес, явище, що вивчається; своєчасне діагностування рівня досягнення навчального результату шляхом надання можливості особам із порушеннями зору продемонструвати власне 
розуміння об'єкта навчання та за потребою здійснити корекцію утвореної в пам'яті фрагментарності й недостатньої узагальненості цього образу.

У дослідженні ми виходили з того, що навчально-розвивальний процес професійної комп'ютерної підготовки осіб із порушеннями зору за своїм змістом має бути побудований на засадах використання методик особистісно орієнтованого розвивального навчання, які 6 сприяли формуванню в незрячих та слабозорих студентів здібностей до критичного мислення i, як наслідок, розвитку їхньої креативності.

У процесі особистісно зорієнтованого розвивального навчання найвищим виявом когнітивного рівня знань у суб'єкта освіти є виявлення ініціативності, здатності до розв'язання нетипових завдань, до відповідальності за ухвалення рішення. Цей рівень за стійкої мотивації особистості із депривацією зору до професійного становлення є умовою для створення в процесі оволодіння адаптивними допоміжними комп'ютерними технологіями компенсаторних пристосувань, рівень сформованості яких буде визначати динаміку розвитку креативного мислення. Відповідно, рівень креативності буде визначатись зростанням самостійності особи 3 порушеннями зору у своїх діях, що характеризуватиме зростання іiі готовності до продукування нових власних ідей.

Креативність, як виявлення індивідуальних здібностей людини, безпосередньо пов'язана з її емоційним станом, який супроводжує процес творчості особистості [3, c. 68]. У процесі організації професійної комп'ютерної підготовки осіб із порушеннями зору на засадах особистісно зорієнтованого розвивального навчання $є$ важливим створення механізмів трансформації когнітивного змісту в емоційний, тобто такий, що $\epsilon$ змістовновизначальним для виявлення креативності зороводепривованої особистості. Отже, особистісно-орієнтоване розвивальне навчання осіб із порушеннями зору в системі професійної комп'ютерної підготовки безпосередньо впливає на розвиток компенсаторних пристосувань до використання комп'ютерної техніки як базового механізму, що сприяє розвитку когнітивності та виявлення креативного мислення суб'єктів освіти, що мають дефект зору.

За цих умов можна визначити механізми компенсаторнорозвивального навчання в процесі професійної комп'ютерної підготовки осіб iз порушеннями зору. Основою компенсаторно-розвивального навчання незрячих та слабозорих студентів $є$ осмислення ними навчальної інформації та прийомів практичної роботи, створення уяви психічних образів фахової діяльності. Осмислення $є$ результатом мисленнєвих процесів, які характеризують етапи компенсаторно-розвивального навчання, за результатами якого відбувається розкриття предметного змісту професійної діяльності у іiї взаємозв'язках.

Кожний етап підготовки осіб із порушеннями зору до професійного застосування комп'ютерних технологій відповідає певним психофізіологічним характеристикам стадій розвитку особистості. Так, перший етап підготовки 
орієнтований на формування в незрячих та слабозорих студентів психічної образної уяви про обрану професію, про фахову діяльність, яка грунтується на використанні комп'ютерної техніки. На цьому етапі підготовки основні методи пов'язані із сенсомоторними діями, які на основі сприймання голосової та тактильної інформації формують образні уяви про апаратні та програмні об'єкти професійної діяльності. Цей етап активізує такі перцептивні операції мисленнєвих процесів, як: розрізнення, ідентифікацію та розпізнавання об'єкту, що пов'язується нами з виникненням у незрячої особи компенсаторних пристосувань.

Другий етап - аналітико-синтетичний передбачає вироблення в незрячих та слабозорих студентів таких особистих якостей, як уважність, концентрація та селективність, які тісно пов'язані 3 елементами когнітивного мислення. Розвиток концентрації уваги успішно впливає на зростання рівня компенсаторних пристосувань, а також виробляє вміння відчувати сутність завдань, що виконуються. Селективність варіантів розв'язку проблеми, шляхом виявлення та уточнення варіантів іiі розв'язку, забезпечує ефективність когнітивного процесу навчання. На цьому етапі в зороводепривованої особистості розвиваються такі мисленнєві процеси, як аналіз і синтез, які реалізуються психічними процесами мислення в напрямі від наочного і конкретного до абстрактного і загального, а від абстрактного - до конкретного.

На третьому етапі підготовки забезпечується розвиток інтелектуальних здібностей особистості з порушеннями зору. Креативне мислення формується на системоутворювальних алгоритмах розумової інтелектуальної діяльності. Інтелектуальний аспект креативності грунтується на таких характеристиках творчого мислення:

- продуктивності, яка виявляється у здатності особистості 3 порушеннями зору генерувати безліч ідей, утворювати асоціації, пропонувати варіанти розв'язання проблеми;

- гнучкості, тобто здатності швидко реагувати на обставини, що виникають, змінювати способи дій, переходити від одного класу об'єктів до іншого;

- оригінальності як виявлення незвичайності, рідкісності й унікальності варіантів розв'язання певної проблеми.

Висновки та перспективи подальших досліджень. Основні засади побудови педагогічного процесу професійної комп'ютерної підготовки у формі інклюзивного навчання грунтуються на врахуванні індивідуальних психофізіологічних особливостей незрячих і слабозорих суб'єктів навчальної діяльності. Дотримання принципів природовідповідності, доступності та емоційності навчання на засадах активної співпраці може бути забезпечено шляхом розроблення індивідуальних програм, запровадження рівневої диференціації підготовки, урахуванням особливостей пізнавальної діяльності та компенсаторних можливостей осіб із порушеннями зору. Впровадження інклюзивного навчання осіб із порушеннями зору у професійно-технічних та вищих навчальних закладах повинно здійснюватись за умови активної 
підтримки процесу навчання системою супроводу в межах якої активно застосовується комп'ютерна техніка, що оснащена СІТА. Це дозволить досягнути очікуваного результату, який полягає в формуванні інформаційно-комунікативної компетентності людей з депривацією зору через оволодіння інформаційними та фаховими знаннями, вміннями та навичками використовувати комп'ютерну техніку у процесі здійснення соціальної та професійної діяльності.

Окреслені підходи створюють передумови для визначення цілей, змісту, методів та засобів навчання в системі професійної комп'ютерної підготовки осіб з порушеннями зору.

\section{Література}

1. Кольченко К. О. Забезпечення інклюзії молоді з інвалідністю в університетське середовище / К. О. Кольченко, Г.Ф.Нікуліна // Актуальні проблеми навчання та виховання людей з особливими потребами : [зб. наук. праць]. - № 6 (8). - К. : Університет «Україна», 2009. - С. 10-15.

2. Инклюзивное образование: методология, практика, технологии : [материалы международной научно-практической конференции (20-22 июня 2011, Москва)] / Моск. гор. психол. пед. ун-т; редкол.: С. В. Алехина и др. - М. : МГППУ, 2011. - 244 с.

3. Пономарев Я. А. Психология творчества / Я. А. Пономарев. - М. : Наука, 1976. - 302 с.

Стаття надійшла до редакції 14.05.2012 p.

УДК821.161.2.-3.09:378.147

Н. В. Романишина, докторант, Національний педагогічний університет ім. М. П. Драгоманова

\section{МЕТОДИКА ФОРМУВАННЯ У СТУДЕНТІВ-ГУМАНІТАРІЇВ ПИСЬМЕННИЦЬКОЇ КОМПЕТЕНТНОСТІ}

Романишина Н.В. Методика формування у студентів-гуманітаріїв письменнищької компетентності.

Автором статті подано методичні рекомендачіï, у яких запропоновано у процесі практики написання твору малої прозової форми виявляти і розвивати у майбутніх учителівсловесників літературне обдарування, вміння віднаходити нюанси мистецької реалізації, долаючи деструктивний автоматизм, стихійне наслідування стилю мития-професіонала.

Ключові слова: письменницька компетентність, текстотворчі вміння, креативність мислення, фантастичний жанр.

Романишина Н. В. Методика формирования у студентов-гуманитариев писательской компетенции.

Автор статьи представляет методические рекомендации, в которых предлагается 6 прочессе практики написания сочинения малой прозаической формы находить и развивать в будущих учителях словесности литературные задатки, умения искать отдельные нюансы артистической реализачии, преодолевая деструктивный автоматизм, слепую и стихийную имитацию стиля писателя-профессионала.

Ключевые слова: писательская компетентность, текстотворческие умения, креативность мышления, фантастический жанр.

Romanishina N.V. The methodics of the forming in students literary competence.

The author of the article offers methodological recommendations, how through the practice of writing short prose works to find and develop in future teachers of literature literary makings, the ability to search for the individual nuances of artistic realization, overcoming destructive automatism, blind and spontaneous imitation of the style of the writer-professional.

Key words: literary competence, textforming skills, creative thinking, fantasy genre. 